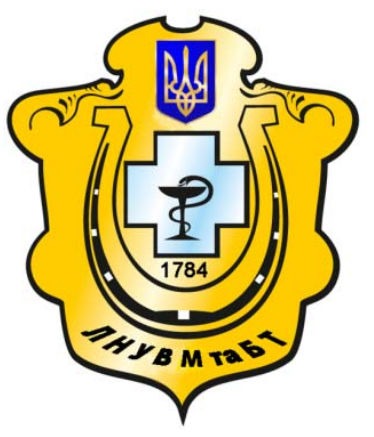

Науковий вісник Львівського національного університету ветеринарної медицини та біотехнологій імені С.3. Гжицького

Scientific Messenger of Lviv National University of Veterinary Medicine and Biotechnologies named after S.Z. Gzhytskyj

doi:10.15421/nvlvet7016

ISSN 2413-5550 print

ISSN 2518-1327 online

$\underline{\text { http://nvlvet.com.ua/ }}$

УДК 636.09:616.99:636.4

\title{
Порівняльна оцінка копроскопічних методів діагностики криптоспоридіозу великої рогатої худоби
}

\author{
М.М. Данко, О.Л. Тішин, Р.В. Хом’як \\ oleksandr.tishyn@gmail.com
}

Державний науково-дослідний контрольний інститут ветпрепаратів та кормових добавок, вул. Донецька, 11, м. Львів, 79000 Україна

\begin{abstract}
Криптоспоридіоз великої рогатої худоби є суттєвою проблемою у переважній більшості країн світу з інтенсивним веденням тваринництва, завдаючи значних економічних збитків. Захворювання проявлясться погіршенням апетиту, пригніченням, діареєю, зниженням приростів, втратою маси тіла, відставанням у рості, а в окремих випадках - загибеллю хворих тварин. Важливе значення в комплексі лікувально-профілактичних заходів криптоспоридіозу великої рогатої худоби належить лабораторній діагностиці, яка дозволяє на ранніх етапах захворювання своєчасно виявити та ідентифікувати збудника. У статті наведено дані щодо порівняльної очінки трьох копроскопічних методів лабораторної діагностики криптоспоридіозу великої рогатої худоби. 3 иією метою було відібрано 10 проб фекаліїв від телят, уражених збудником Cryptosporidium parvum, до яких додавали фізіологічний розчин та центрифували. 3 отриманої суспензії виготовляли мазки та зафарбовували азур-еозином (за Гімзою), карбол-фуксином (за Цілем-Нільсеном), сафраніном (за Кестером). За результатами проведених досліджень найнижчий показник виявлення ооиист криптоспоридій отримано за фарбування мазків азур-еозином. Найбільш ефективним копроскопічним методом детекиії ооцист криптоспоридій великої рогатої худоби виявився метод фарбування мазків за Кестером. Середня кількість ооиист криптоспоридій, виявлених даним методом, була у 1,9 рази вища, ніж за методом Гімзи та у 1,4 рази -за методом Ціля-Нільсена.

Ключові слова: Cryptosporidium, криптоспоридіоз, кокиидї, оочичсти, найпростіші, інвазія, телята, велика рогата худоба, копроскопія, діагностика, фарбування мазків.
\end{abstract}

\section{Сравнительная оценка копроскопических методов диагностики крипто- споридиоза крупного рогатого скота}

\author{
М.М. Данко, А.Л. Тишин, Р.В. Хомяк \\ oleksandr.tishyn@gmail.com
}

Государственный научно-исследовательский контрольный институт ветеринарных препаратов и кормовых добавок, ул. Донеикая, 11, г. Львов, 79000, Украина

\begin{abstract}
Криптоспоридиоз крупного рогатого скота является существенной проблемой в большинстве стран мира с интенсивным ведением животноводства, нанося значительный экономический ущерб. Заболевание проявляется ухудшением аппетита, угнетением, диареей, снижением приростов, потерей массы тела, отставанием в росте, а в отдельных случаях гибелью больных животных. Важное значение в комплексе лечебно-профилактических мероприятий криптоспоридиоза крупного рогатого скота принадлежит лабораторной диагностике, которая позволяет на ранних этапах заболевания своевременно выявить и идентифицировать возбудителя. В статье приведены данные по сравнительной оценке трех копроскопических методов лабораторной диагностики криптоспоридиоза крупного рогатого скота. С этой иелью было отобрано 10 проб фекалий от телят, инвазированных возбудителем Сryptosporidiuт рагvит, к которым добавляли физиологический раствор и иентрифугировали. Из полученной суспензии изготавливали мазки и окрашивали азур-эозином (по Гимзе), карбол-фуксином (по Целю-Нильсену), сафранином (по Кестеру). По результатам проведенных исследований наиболее низкий показатель вылвления ооцист криптоспоридий получено при окраске мазков азур-эозином. Наиболее эф-
\end{abstract}

Citation:

Danko, M.M., Tishyn, O.L., Khomyak, R.V. (2016). Comparison of coprological methods for diagnosis of cattle cryptosporidiosis. Scientific Messenger LNUVMBT named after S.Z. Gzhytskyj, 18, 3(70), 71-73. 
фективным копроскопическим методом детекиии оочист криптоспоридий крупного рогатого скота оказался метод окраски мазков по Кестеру. Среднее количество ооцист криптоспоридий, выявленных данным методом, была в 1,9 раза выше, чем по методу Гимзы и в 1,4 раза-по методу Целя-Нильсена.

Ключевые слова: Cryptosporidium, криптоспоридиоз, кокцидии, ооцисты, простешие, инвазия, телята, крупный рогатый скот, копроскопия, диагностика, окрашивание мазков.

\title{
Comparison of coprological methods for diagnosis of cattle cryptosporidiosis
}

\author{
M.M. Danko, O.L. Tishyn, R.V. Khomyak \\ oleksandr.tishyn@gmail.com
}

\begin{abstract}
State scientific-research control institute of veterinary medicinal products and feed additives, Donetsk Str., 11, Lviv, 79000, Ukraine
\end{abstract}

\begin{abstract}
Cryptosporidiosis in cattle is a significant problem in most countries with intensive livestock, causing significant economic losses. The disease manifests appetite loss, depression, diarrhea, decreased growth, weight loss, retarded growth, and in some cases death of sick animals. Equally important in the complex treatment and prevention of bovine cryptosporidiosis owned laboratory diagnostics, which allows early disease promptly detect and identify the pathogen. The article presents data on comparative assessment of three coprological methods of laboratory diagnosis of cryptosporidiosis in cattle. For this purpose, selected 10 samples of feces from calves infected with Cryptosporidium parvum, which added saline and were centrifuged. From the resulting suspension made smears and painted over by azure-eosin (by Giemsa) karbol-fuchsin (by Ziehl-Neelsen) safranine (by Kester). The results of the research identifying the lowest Cryptosporidium oocysts obtained by staining smears azure-eosin. Most effective method of detecting Cryptosporidium oocysts in cattle was staining method strokes by Kester. Average Cryptosporidium oocysts detected by this method was 1.9 times higher than Giemsa method and by 1.4 times - than Ziehl-Neelsen method.
\end{abstract}

Key words: Cryptosporidium, cryptosporidiosis, coccidia, oocysts, protozoa, invasion, calf, cattle, coproscopy, diagnostic, smear staining.

\section{Вступ}

Криптоспоридіоз - протозойне зоонозне захворювання тварин та людини, яке спричинюють кокцидії роду Cryptosporidium, характеризується ураженням епітелію внутрішніх органів, зокрема кишечнику та органів дихання. Ендогенні стадії криптоспоридій розмножуються в епітеліальних клітинах кишечнику, призводячи до запальних процесів різної важкості. Криптоспоридіоз $є$ одним із основних патогенних чинників, що спричинює виникнення діареї у телят. У великої рогатої худоби паразитує чотири види криптоспоридій: Cryptosporidium parvum, C. andersoni, C. bovis, C. ryanae (Thompson and Smith, 2011; Yong-il and Kyoung, 2014).

Криптоспоридіози поширені повсюдно. Показник інвазованості великої рогатої худоби у країнах Європи складає: в Данії - 96\%, Норвегії - 72\% (Robertson and Björkman, 2014), Швеції - 96\% (Björkman et al., 2015), Австрії - 11\%, Німеччині - 21,5\% (Joachim et al., 2003), Польщі - 51\% (Bednarska et al., 1998).

Клінічно криптоспоридіоз проявляється у телят 3 30-добового віку, пік захворюваності найчастіше припадає на 7 - 15 добу життя. Залежно від перебігу захворювання у хворих тварини відмічають погіршення апетиту, пригнічення, спрагу, зниження середньодобивих приростів, втрату маси тіла, відставання у рості, діарею зі слизом, іноді 3 домішками крові. За важкого перебігу тварини важко встають, лежать, погано реагують на зовнішні подразники, очі тьмяні, слизові оболонки сухуваті, синюшні. Спостерігається тахікардія, м'язове тремтіння, втрата тактильної чутливості. За відсутності своєчасного лікування захворювання ускладнюється пневмонією, що часто призводить до загибелі тварин (Radostits et al., 2008).
Лабораторні методи дослідження 3 виявлення ооцист криптоспоридій $є$ обов'язковими для остаточного підтвердження діагнозу на криптоспоридіоз.

В останні роки великого значення набув метод полімеразно-ланцюгової реакції (PCR), який дає змогу виявляти збудників криптоспоридіозу, враховуючи ряд морфологічних та генетичних особливостей, тим самим забезпечуючи їхню ідентифікацію на будь-якій стадії розвитку. При цьому чутливість даного методу може досягати 100\% (Bhat et al., 2014).

Проте, в щоденній ветеринарній практиці найбільшого поширення набули дослідження мазків, виготовлених із збагаченого досліджуваного матеріалу й зафарбовані за класичними методами, що застосовуються в мікробіології та гістологї (Bogach et al., 2014; Rekha et al., 2016).

\section{Матеріал і методи досліджень}

Нами було проведено порівняльну оцінку трьох методів виявлення ооцист криптоспоридій шляхом фарбування мазків азур-еозином за Гімзою, карболфуксином за Цілем-Нільсенем, сафраніном за Кестеpoм.

Виявлення ооцист кокцидій проводили згідно наступної процедури: до відібраних зразків фекаліїв (10 проб) додавали фізіологічний розчин $з$ метою утворення гомогенної маси, яку фільтрували через подвійний шар марлі та центрифугували за швидкості 3000 обертів за хвилину впродовж п'яти хвилин. 3 осаду виготовляли нативні мазки за загальновизнаною методикою. Після висушування їх фіксували і фарбували за методами Гімзи, Ціля-Нільсена та Кестера (Klymnjuk et al., 2004). 
Підрахунок криптоспоридій проводили шляхом визначення середньої кількості ооцист у 10 полях зору мікроскопу (Rekha et al., 2016).

Ідентифікацію криптоспоридій проводили за визначником (Krylov, 1996), беручи до уваги форму, колір, розміри ооцист. Біометрію здійснювали за допомогою мікроскопу за збільшення $\times 400$.

\section{Результати та їх обговорення}

За результатами проведених досліджень встановлено наявність у пробах фекалій телят ооцисти виду Cryptosporidium parvum (табл. 1).

Наведені у таблиці дані свідчать про низьку ефективність фарбування мазків за Гімзою за копроскопічної діагностики криптоспоридіозу великої рогатої худоби. Фарбування мазків за Ціль-Нільсеном показало на 26,6\% вищу ефективність порівняно з методом Гімзи. Найбільш ефективним виявився метод фарбування мазків за Кестером. Середня кількість ооцист криптоспоридій виявлених даним методом була у 1,9 разів вища, ніж за методом Гімзи та у 1,4 рази - за методом Ціля-Нільсена.

Таблиия 1

Частота виявлення ооцист криптоспоридій за допомогою різних методів фарбування мазків фекаліїв $(\mathbf{n}=\mathbf{1 0})$

\begin{tabular}{|l|c|}
\hline $\begin{array}{c}\text { Метод копроскопічного } \\
\text { дослідження }\end{array}$ & $\begin{array}{c}\text { Середня кількість ооцист у } \\
\text { 10 полях зору мікроскопу }\end{array}$ \\
\hline $\begin{array}{l}\text { Фарбування мазків за } \\
\text { Кестером }\end{array}$ & $10,1 \pm 0,90$ \\
\hline $\begin{array}{l}\text { Фарбування мазків за } \\
\text { Гімзою }\end{array}$ & $5,22 \pm 0,84$ \\
\hline $\begin{array}{l}\text { Фарбування мазків за } \\
\text { Цілем-Нільсенем }\end{array}$ & $7,11 \pm 0,82$ \\
\hline
\end{tabular}

\section{Висновки}

У порівняльному аспекті найбільш ефективним методом копроскопічної діагностики криптоспоридіозу великої рогатої худоби виявився метод фарбування мазків за Кестером. Даний метод показав на 29,6\% вищу ефективність порівняно 3 методом ЦіляНільсена та на 48,3\% - методом Гімзи.

Перспективи подальших досліджень. Вивчення ефективності дезінфікуючих засобів по відношенню до збудників криптоспоридіозу великої рогатої худоби.

\section{Бібліографічні посилання}

Thompson, R.C.A., Smith, A. (2011). Zoonotic enteric protozoa, Vet. Parasitol. 18, 70-78.

Yong-il, C., Kyoung, Y. (2014). An overview of calf diarrhea - infectious etiology, diagnosis, and intervention. J. Vet. Sci, 15(1), 1-17.

Robertson, L.J. Björkman, C. (2014). Cryptosporidiosis in farmed animals. In Cryptosporidium: Parasite and Disease, Springer-Verlag. 149-235.

Björkman, C., Lindström, L., Oweson, C. et al. (2015). Cryptosporidium infections in suckler herd beef calves. 42, 1108-1114.

Joachim, A., Krull, T., Schwarzkopf, J., Daugshies, A. (2003). Prevalence and control of bovine cryptosporidiosis in German dairy herds. Vet. Parasitol. 112(4), 277-288.

Bednarska, M. Bajer, A., Siński, E. (1998). Calves as a potential reservoir of Cryptosporidium parvum and Giardia sp., Ann. Agric. Environ. Med, 5(2), 135138.

Radostits, O.M., Gay, C.C., Hinchcliff, K.W. et al. (2008). Diseases associated with protozoa. 10th Edn. In: Veterinary Medicine: A Textbook of Diseases of cattle, horses, sheep, pigs, and goats, Saunders Elsevier. 1483-1540.

Bhat, S.A., Dixit, M., Juyal, P.D., Singh, N.K. (2014). Comparison of nested PCR and microscopy for the detection of cryptosporidiosis in bovine calves. J. Parasit. Dis. 38(1), 101-105.

Bogach, M.V., Kuklin, O.Je., Kovalenko, G.A. (2014). Metody diagnostyky kryptosporydiozu ptyci, Veterynarna medycyna Ukrai'ny, 10, 25-27 (in Ukrainian).

Rekha, H.K.M., Puttalakshmamma, G.C., D'Souza, P.E. (2016). Comparison of different diagnostic techniques for the detection of cryptosporidiosis in bovines, Vet. World. 9, 231-215.

Klymnjuk, S.I., Sytnyk, I.O., Tvorko, M.S., Shyrobokov, V.P. (2004). Praktychna mikrobiologija: Posibnyk. Ternopil': Ukrmedknyga (in Ukrainian).

Krylov, M.V. Opredelytel' parazytycheskyh prostejshyh (cheloveka, domashnyh zhyvotnyh y sel'skohozjajstvennyh rastenyj), SPb: Zoologycheskyj ynstytut RAN (in Ukrainian).

Стаття надійшла до редакиії 11.09.2016 